\title{
Social Capital Impact On Service Supply Chains
}

Sherry L. Avery, University of Texas at Arlington, USA

Patricia M. Swafford, University of Texas at Arlington, USA

\begin{abstract}
Purpose - This study explores the impact of social capital on service firm supply chains.

Design/methodology/approach - The theoretical underpinnings of social capital is reviewed from various disciplines, including sociology, management, and operations management. This is used to develop a conceptual model of the use of social capital in a service supply chain setting.

Findings - Social capital is proposed to improve the operational performance of service firms as a source of both physical and information resources. The impact of social capital is projected to vary by firm size and service type. Small firms have limited resources and thus a need for resources obtained through social capital. Service firms that have high customization and customer contact are subject to process variations which can be mitigated by social capital. A conceptual model is presented to test several propositions related to social capital.

Originality/value - The impact of social capital has not been widely studied in an operational setting. This is the first known study to specifically analyze the impact of social capital in service supply chains.
\end{abstract}

Keywords: conceptual paper, social capital, service supply chain

\section{INTRODUCTION}

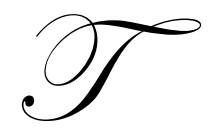

he service industry is vital to the U.S. economy given that as of January 2008 there were $116,095,000$ service jobs compared to 21,907,000 manufacturing jobs (U.S. Labor of Statistics website). [1] Thus is it interesting that research on service operations management (SOM) by operations management $(\mathrm{OM})$ researchers has been minimal [2]. Given the increasing important of the service sector to the U.S. economy, we seek to gain more understanding of the unique challenges in managing a service supply chain and the impact of social capital on service supply chain performance. One question that OM researchers struggle with is why do some service supply chains perform better than other service supply chains? Important insight regarding this question may be provided by considering the concept of social capital and its effects. Thus, we begin by reviewing the concepts of social capital and supply chain within a service context. Based on these discussions and existing literature, we propose a model concerning the impact of social capital on the service supply chain performance.

\section{THEORETICAL FOUNDATIONS OF SOCIAL CAPITAL}

There are many definitions of social capital used in academic research. Beginning with Coleman (1988), he stated that social capital is based on the structures of relations between actors and it facilitates actions of actors, both in a personal and business setting. Portes (1988) indicated that social capital is the ability of an individual to obtain benefits through membership in social networks. Nahapiet and Ghoshal (1998) defined social capital as, "the sum of the actual and potential resources embedded within, available through, and derived from the network of relationships possessed by an individual or social unit." Lin (2001) conducted a review of social capital and concluded that social capital are "resources embedded in social networks accessed and used by actors for actions."Adler and Kwon (2002) identified multiple definitions of social capital used in social sciences. They used these definitions to build a composite definition that focuses on goodwill as the foundation of social capital. "Social capital is the goodwill available to individuals or groups. Its sources lie in the structure and content of the actor's social relations. Its effects flow from the information, influence, and solidarity it makes available to the actor." 
Thus, according to the similarities in these definitions, social capital is based on (1) individual actors within a social network setting, (2) resources must be available and exchanged, and (3) these resources result in positive outcomes.

From these definitions, it is clear that networks play an important role in social capital. It is through networks of people and organizations that social capital is exchanged. Networks provide the opportunity for people to exchange goods, services, and information. It is within networks of mutual acquaintances that social capital is embedded. The relationships between and among people in a network constitute a valuable resource to exchange social capital [3,4]. Networks exist in different forms such as an intracorporate network, strategic alliance or an industrial district. An intracorporate network is a group of organizations operating under a unified corporate identity with its headquarters having a controlling interest in its subsidiaries [5]. A strategic alliance is a group of firms entering into voluntary arrangements that involve exchange, sharing, or codevelopment of products, technologies or services [6,7]. An example of a strategic alliance could be an alliance between a firm (buyer) and key supplier, say between Intel and IBM. An industrial district is a network comprising independent firms operating in the same or related market segment and a shared geographic locality benefiting from external economies of scale [8]. An example of an industrial district is Silicon Valley.

Social capital can be exchanged throughout any type of network. It can be accessed through internal ties within the firm or external ties with outside individuals or organizations. While social capital cannot exist without a network, the existence of a formal network or community tie does not ensure the existence of social capital. Along with its actors and network, social capital also involves structural, cognitive, and relational aspects. The structural aspect is based on network ties, network configuration, and network stability of the network or community in which the individual resides. The cognitive aspect represents the shared meaning and understanding between members in the network as well as their shared goals and culture. The relational aspect reflects the direct ties between actors and the relational outcomes of interactions. In essence, this is the personal relationship between parties [3].

Social capital is based on trust, repeated interactions, cooperative behavior, and availability of an ability or resource. Trust plays a key role in the willingness of network actors to share knowledge, based on social judgments and assessment of the cost. If parties trust each other, they are more willing to engage in cooperative activity that results in further trust being generated [4]. Therefore it serves as a form of governance mechanism. Also, trust diminishes opportunism and the need for monitoring as well as encourages cooperative behavior which facilitates the development of new products and processes.

Capital can be either tangible or intangible. Tangible forms of capital include financial and physical capital while intangible capital cannot be seen. An example of an intangible capital is intellectual capital that represents the intellect residing in the heads of a firm's employees. In a similar sense, social capital is a form of intangible capital. While an intangible capital, social capital shares many of the characteristics of physical capital. One, it is a long lived asset that can last for many years. For example, a firm invests in new plant equipment with the expectation of cost savings in the future. People also invest in social capital with the expectation of future benefits in the form of physical or informational resources. Two, it is appropriable since it can be used for more than one purpose. For example, a relationship made within a trade organization could be used in both supplier and personal acquisitions. Three, it can be converted to an economic advantage as a substitute for or complement to other assets; thus be able to help make up for the lack of financial resources or human capital. Four, it also needs maintenance given that relationships between actors, just like friendship, have to be maintained [9]. In light of these similarities, there is a key difference between social capital and other assets. This key difference is that social capital is owned jointly by the parties in a relationship [10]; thus no one person has exclusive ownership rights.

There are several benefits for a firm having social capital. Social capital makes it possible to achieve ends that would be impossible without it or could be achieved only at extra costs [3,11]. Benefits include privileged access to knowledge and information, preferential opportunities for new business, enhanced reputation, influence, and understanding of network norms [5]. Adler and Kwon (2002) identified three key benefits of social capital: (1) Social capital provides information through access to broader sources of information and improves information's quality, relevance, and timeliness. (2) Influence, control, and power results due to the exchange of resources. Individuals in position of power can influence social networks norms. (3) Strong social norms and belief provide solidarity which encourages compliance with the norms of the network and reduces the need for formal contracts. 
Social capital can increase the efficiency of action through minimizing redundancy. Given its benefits, one can easily see the importance of understanding the nature in which social capital can be built and tapped within a firm.

\section{SOCIAL CAPITAL IN RESEARCH SETTINGS}

The study of social networks began in the sociology discipline where studies of communities originally focused on the importance of a social network. Studies found that networks of strong, personal relationships developed over time based on trust, cooperation, and collective action will strengthen communities [12]. Coleman (1988) introduced the concept of social capital in his article in which he examined the impact of social capital on the dropout rates in local high schools. Using various measures of social and human capital, the study found that the existence of positive social capital decreased dropout rates. For example, the number of adults in the family and their expectations for college impacted dropout rates. The study also found that students who attended religious private schools and whose families were active in church attendance had a lower dropout rate [11].

The strategic management and organizational behavior disciplines have used social capital and social network theory in a number of research studies since the 1980s. Adler and Kwon (2002) conducted a review of social capital research in an organizational setting in which they cited several studies that showed social capital having a positive impact in a number of job related situations. Some of these situations include career success, finding jobs, inter-unit resource exchange and product innovation, increased intellectual capital, reduced turnover rates, and stronger supplier relations. Tsai and Ghoshal (1998) studied a large multinational electronics company and found positive affects due to social capital. Koka and Prescott (2002) studied the impact of social capital on the global steel industry. Many studies of entrepreneurship are based on network and social capital theory [13, 14]. Also, network and social capital theory research is emerging in the information technology discipline [15]. Even marketing academics have used social capital theory as an explanation of firm performance. For example, a recent study of Chinese businesses found that relationships are a source of resources [16].

Within the last five years, the operations management (OM) field has begun to use social capital theory in studies of supply chain management and knowledge/learning. Supply chains, specifically buyer seller relationships, are a major focus in the OM field. For example, a study of U.S. automotive and electronic industries found that strong relationships with suppliers improved supply chain performance [17]. Another study found that relational capital improves buyer seller relations [18] while yet another study found that relational capital had a positive impact on buyer performance [19]. Obviously, social capital has a potential to be a rich source of research surrounding supply chains.

\section{SERVICE SUPPLY CHAINS}

Specifically, a supply chain is a network of organizations that are involved--through upstream and downstream linkages--in the different processes and activities that produce value in the form of products and services in the hands of the ultimate customer [20]. Supply chains provide the structure to build social networks that can be used to exchange social capital. While service firms can also use supply chains, service operations have unique characteristics not found in manufacturing firms [21]. The main source of the uniqueness is the element of customer involvement in the process. These unique characteristics of services include:

1. Customer-supplier duality. Services act on customers' minds, bodies, or possessions, therefore customers are an integral part of the process. This results in customers as both a source of input and output. The quality of the customer input can introduce variations and uncertainties in the process. For example, the individual who visits a general practitioner physician is both the source of the input (the illness) and the source of the output of the process (the cure.) The ability of the patient to accurately portray the symptoms can improve the ability of the physician to diagnose the true cause of the problem. [22].

2. Perishable. Utilization of capacity is limited to present customer demand [23]. Service businesses cannot use inventory as a buffer for variations in demand. Unused capacity is lost forever, such as idle time of the workforce or an empty seat on an airplane, train, or hair salon station.

3. Heterogeneity. Every customer has unique needs, which requires the services to be tailored to their needs. Again, this level of customization introduces variability and uncertainty into the process. For example, 
every patient of a general practitioner physician could have a different problem which requires a different process to heal. [23].

4. Labor intensive - Services tend to be much more labor intensive than manufacturing [22]. Automation is difficult to introduce in a service environment; for example, a haircut or a physician's consultation cannot be automated. Therefore, labor is often a major portion of the operating expense of a service operation. Uncertainty surrounding demand and variations makes it difficult to accurately forecast staffing requirements.

All of these characteristics provide unique challenges in managing a service supply chain. In addition, a typical service supply chain has fewer supply levels than a manufacturing supply chain and the flow of resources and information are intricately intertwined. [22]. Figure 1 illustrates a service supply chain that shows the service firm is typically a hub with both suppliers and customers exchanging both resources and information. Social capital is shown as a source of resources, which includes both customers and suppliers.

Figure 1: Service Supply Chain

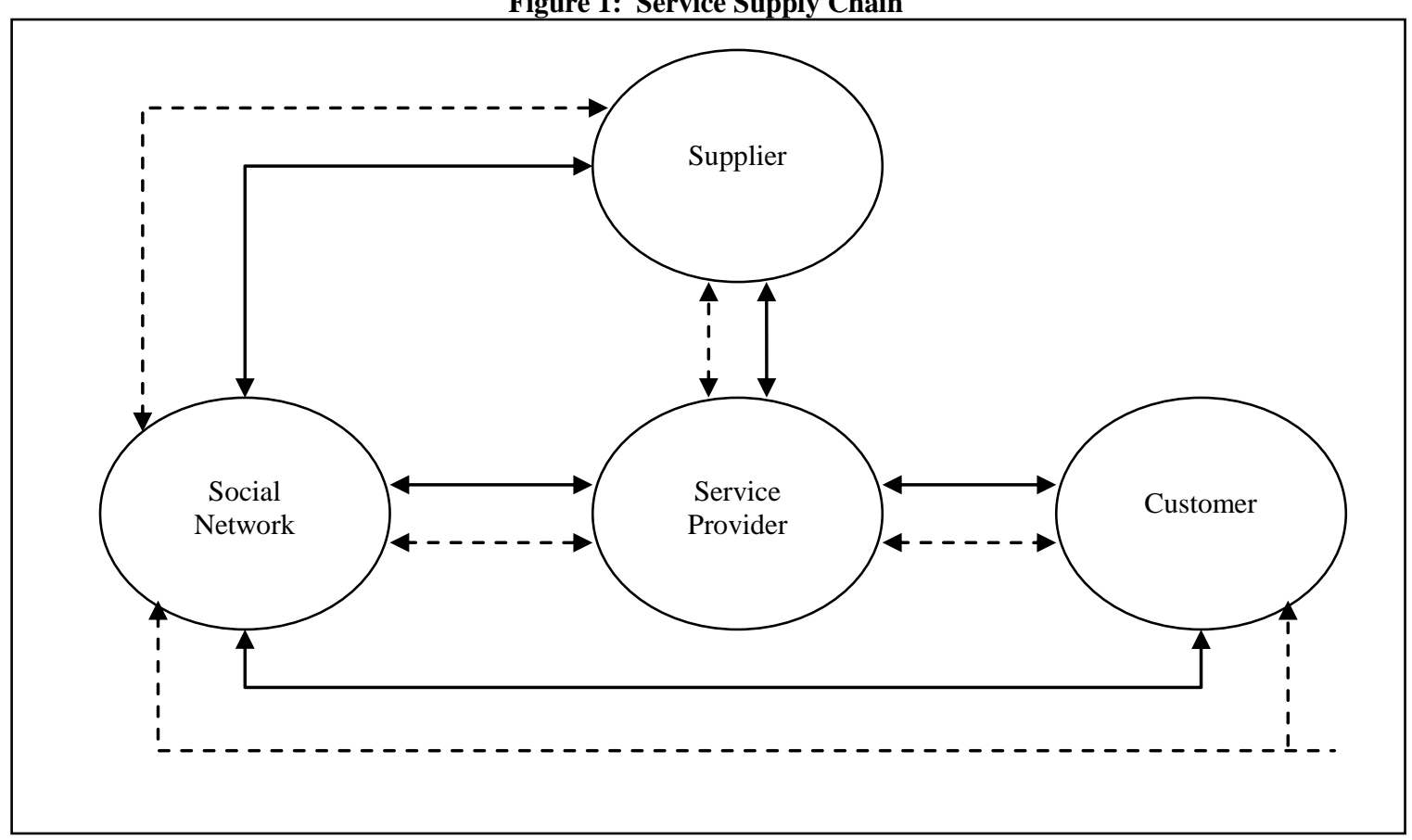

Note: Solid lines denote resources. Dotted lines denote information.

Consistent with other authors, this manuscript proposes that the differences between manufacturing and service firms are significant enough to warrant specific studies targeted at service firms. For example, Akkermans and Vos reviewed amplification (bullwhip effects) in service supply chains. They concluded that measures used to address amplification in manufacturing supply chains may not be effective in service supply chains [21]. A recent study of health care supply chains found that the level of customization of service and degree of participation of the customer provide an overall uncertainty to the basic process [24].

\section{SOCIAL CAPITAL IN SERVICE SUPPLY CHAINS}

Service supply chains are uniquely positioned to take advantage of social networks because many of the relationships are both personal and professional. Service firms tend to use their networks of friends and 'friends of friends' to obtain information, customers, suppliers, and even resources. For example, a general practitioner physician may build up a series of relationships with several specialists. If he has a patient needing cardiac care, he can send him to a cardiologist that he knows and trusts. If he has a patient with symptoms he cannot diagnose, he 
can contact his peers for consultations. If he has a patient that needs an MRI, he can send them to another facility that has an MRI. The end result, hopefully, is a well patient. A strong network of social capital can provide the service supply chain access to both resources and information.

Proposition 1: Social capital has a positive impact on the performance of a service firm's supply chain.

\section{SERVICE STRUCTURE}

Various typologies have been developed to provide a way to understand and research the wide range of service configurations. These typologies are used to classify and categorize service organizations based on a number of characteristics. This provides a method to understand commonalities in order to learn and search for common experiences and solutions. Table 3 summarizes various classification schemas obtained from operations management literature.

Table 3: Service Typologies

\begin{tabular}{|l|c|l|l|}
\hline \multicolumn{1}{|c|}{ Authors } & Year & \multicolumn{1}{c|}{ Concept } & \multicolumn{1}{c|}{ Classification based on: } \\
\hline Maister and Lovelock & 1982 & Facilitators of transactions & $\begin{array}{l}\text { Customer contact } \\
\text { Customization }\end{array}$ \\
\hline Chase & 1983 & Operating efficiency of 'technical core' & - Customer contact \\
\hline Schmenner & 1986 & Labor & $\begin{array}{l}\text { Labor intensity } \\
-\end{array}$ \\
\hline Kellogg and Nie & 1995 & Strategic, focused on customer influence & $\begin{array}{l}\text { - Service process "How" } \\
\text { - Service package "What" }\end{array}$ \\
\hline
\end{tabular}

The Maister and Lovelock 1982 model is based on the concept that businesses are facilitators of transactions. Activities performed by service businesses include buying and selling goods and services, like travel agencies, real estate, and employment agencies. Their definition excludes retail institutions that takes possession of a physical product, and then resells it. Their model uses the extent of customer contact and extent of customization in the process. This results in four categories: (1) low customer contact, low customization - factories; (2) high customization - mass services; (3) high customer contacts, low customization - job shop; and (4) high customer contact, high customization - professional service [25].

The Chase 1983 model is based on the level of customer contact in providing a service. The presence of the customer in the process is a critical constraint on operational efficiency because the processes to provide a service must be tailored to the level of customer contact. The customer contact model states that operating efficiency is a function of the degree to which the customer is in direct contact with the service facility relative to a total service creation time for the customer. Service systems fall upon a continuum of high customer contact to low customer contact defining contact as the amount of time the customer is in the service system. Theory for the model is based on the technical core which states that the technical core should be sealed off from environmental influences to increase processing efficiency. The model classifies service firms into pure service, mixed service, and quasi-manufacturing. Pure services focus mainly on providing a service, such as a hair salon or general practice physician, with each process focused around a customer. Mixed services include branch offices with back office support for routine processing of transactions and front office support for customer contact; such as banks and insurance companies. Quasi-manufacturing services have structures similar to manufacturing' such as home offices and distribution centers [26].

The service process matrix developed by Schmenner in 1986 is based on the degree of labor intensity and the degree of customer interaction/customization. This results in four classifications: (1) Service factories are low labor, and low interaction/customization; for example airlines, hotels, resorts, and recreation. (2) Service shops are low labor and high interaction/customization; for example, hospitals and auto repair. (3) Mass services are high labor and low interaction/customization, for examples retailing, wholesaling, and schools. (4) Professional services are high labor and high interaction/customization For examples physicians, lawyers, accountants, and architects [27]. 
Kellogg and Nie developed the service process/service package matrix in 1995 [28].. Their model addresses unique strategic issues found in service businesses. The model focuses on customer influence, the service process ('how' we create services) and service package ('what' we create.) They do not claim that all services can fit into this matrix, but most can.

Researchers have not agreed on a common service process structure classification scheme. There is agreement that there are different types of service firms that have different operating requirements and requires different management strategies. The impact of social capital may vary based on the type of service structure. Services with high customer contact and high customization have the potential for variation in the process. For this study, these services are considered pure service firms Inventories are not an option for pure service firms to address variations in demand or process [21]. It is expected that pure services would have the greatest need for a network of resources to meet variations in process or demand and business uncertainties.

P2: Social capital will improve the supply chain operations of service firms with significant variation in processes, specifically 'pure' service firms.

\section{FIRM SIZE}

Small and medium size firms (SMEs) provide a key role in today's economy because of their flexibility and ability to innovate provide new products and services and they are a major source of employment [29]. Entrepreneurship studies have identified that firm size limits the resources available to the firm. Networks were found to be a source of resources that aided small firms in international ventures [30]. Coviello and Munro (1997) conducted a study of small software firms entering into an international venture and found that network relationships were important to the success of the venture. Large firms have more flexibility to devote to supply chain activities and have a stronger power base with suppliers than smaller firms. Social capital is even more important to the overall performance of small service business supply changes than large service business supply chains. Small firms have fewer resources than larger firms; therefore they have to rely on resources obtained through their network. Because of these limited resources, small service supply chains will benefit the most from collaborative efforts [31].

P3: Social capital has a greater impact on the performance of small service firms supply chains than larger firms.

\section{CONCLUSION}

Social capital can be an important component of the successful performance of a service supply chain as a source of both physical and informational resources. These resources can be used to offset the variability inherit in service operations. Small firms with limited resources and pure service firms with process variations due to customization will especially benefit from social capital.

Social capital in service supply chains has the potential to be a valuable and interesting stream of research. The next obvious step is to empirically test the propositions in a service operations environment. Future studies could be expanded to include the impact of firm age on social capital. Older firms should have a stronger social capital than younger firms just by the fact that they have been in existence longer. Studies could focus on just one form of service structure or an individual industry, like Health Care. There could be studies based on the different components of social capital to define which is the most efficient in obtaining knowledge or resources. Additional research on social capital could benefit practitioners and further the knowledge base of operations management research.

\section{AUTHOR INFORMATION}

Sherry Avery, Department of Information Systems and Operations Management, College of Business, University of Texas at Arlington.

Sherry Avery is in her fourth year of the Operations Management Ph.D. program at University of Texas at Arlington. She received her Bachelor of Science degree from the University of Central Oklahoma in Business 
Education and a Master of Science degree in Accounting from the University of Oklahoma. Her research and teaching interests include operations, service industry, supply chains, social capital, RFID, and performance measurements. She has over 20 years of management experience in the service industry.

Dr. Patricia Swafford, Assistant Professor, Department of Information Systems and Operations Management, University of Texas at Arlington.

Dr. Swafford received her Ph.D. in Operations Management from the Georgia Institute of Technology in 2003. She earned both her Bachelor of Science and Master of Science in Industrial Engineering from Clemson University. She also spent several years working in industry within operations management settings. Her teaching and research interests are in operations and supply chain management, information technology applications in value chain management, and service operations.

\section{CITATIONS}

1. U.S. Department of Labor Bureau of Statistics. [cited; Available from: www.bls.gov.

2. Machucha, J.A.D., d.M. Gonzalez-Zamora, and V.G. Aguilar-Escobar, Service operations management research. Journal of Operations Management, 2007. 25: p. 582-603.

3. Nahapiet, J. and S. Ghoshal, Social capital, intellectual capital, and the organizational advantage. Academy of Management Review, 1998. 24(2): p. 242-266.

4. Tsai, W. and S. Ghoshal, Social capital and value creation: The role of intrafirm networks. Academy of Management Journal, 1998. 41(4): p. 464-476.

5. Inkpen, A.C. and E.W.K. Tsang, Social capital, networks and knowledge transfer. Academy of Management Review, 2005. 30(1): p. 146-165.

6. Gulati, R., Alliances and networks. Strategic Management Journal, 1998. 19: p. 293-317.

7. Gulati, R., N. Nohria, and A. Zaheer, Strategic networks. Strategic Management Journal, 2000. 21(3): p. 203-215.

8. Brown, J.E. and C. Hendry, Industrial districts and supply chains as vehicles for managerial and organizational learning. International Studies of Management and Organization, 1998. 27(4): p. 127-157.

9. Adler, P.S. and S.W. Kwon, Social capital: Prospects for a new concept. Academy of Management Journal, 2002. 27(1): p. 17-40.

10. Burt, R.S., Structural holes: The social structure of competition. 1992, Cambridge, MA: Harvard University Press.

11. Coleman, J.C., Social capital in the creation of human capital. The American Journal of Sociology, 1988. 94: p. 95-120.

12. Jacobs, J., The death and life of great American cities. 1965, London: Penguin Books.

13. Birley, S., The role of networks in the entrepreneurial process. Journal of Business Venturing, 1985. 1(1): p. 107-117.

14. Jarillo, J.C., Entrepeneurship and growth: The strategic use of external resources. Journal of Business Venturing, 1989. 4(2): p. 133-147.

15. Balijepally, V., S. Nerur, and R. Mahapatra, IT value of software development: A multi-theoretic perspective, in working paper. 2007, University of Texas at Arlington.

16. Luo Xueming, et al., The Effects of Customer Relationships and Social Capital on Firm Performance: A Chinese Business Illustration. Journal of International Marketing, 2004. 12(4): p. 25-45.

17. Krause, D.R., R.B. Handfield, and B.B. Tyler, The relationships between supplier development, commitment, social capital accumulation and performance improvement. Journal of Operations Management, 2007. 25(2): p. 528-545.

18. Cousins, P.D., et al., Creating supply chain relational capital: The impact of formal and informal socialization processes. Journal of Operations Management, 2006. 24: p. 851-863.

19. Lawson, B., B.B. Tyler, and P.D. Cousins, Antecedents and consequences of social capital on buyer performance improvement. Journal of Operations Management, 2008. 26(3): p. 446-460.

20. Christopher, M., Strategic Manufacturing for Competitive Advantage. 1998, London: Prentice Hall.

21. Akkermans, H. and B. Vos, Amplification in service supply chains: An exploratory case study from the telecom industry. Production \& Operations Management, 2003. 12(2): p. 204-223. 
22. Fitzsimmons, J. and M. Fitzsimmons, Service Management Operations: Operations, Strategy, and Information Technology. 5th ed. 2006, New York: McGraw-Hill/Irwn.

23. Foster Jr., S.T., S.E. Sampson, and S.C. Dunn, The impact of customer contact on environmental initiatives for service firms. International Journal of Operations \& Production Management, 2000. 20(2): p. 187-203.

24. Pitta, D.A. and M.V. Laric, Value chains in health care. Journal of Consumer Marketing, 2004. 21(7): p. 451-464.

25. Maister, D.H. and C.H. Lovelock, Managing Facilitator Services. Sloan Management Review, 1982. 23(4): p. 19-31.

26. Chase, R.B. and D.A. Tansik, The customer contact model for organization design. Management Science, 1983. 29(9): p. 1037-1050.

27. Schmenner, R.W., How can service businesses survive and prosper? Sloan Management Review, 1986. 27(3): p. 21-32.

28. Kellogg, D.L. and W. Nie, A framework for strategic service management. Journal of Operations Management, 1995. 13(4): p. 323-337.

29. Gunasekaran, A., L. Forker, and B. Kobu, Improving operations performance in a small company: a case study. International Journal of Operations \& Production Management, 2000. 20(3): p. 316-335.

30. Oviatt, B.M. and P.P. McDougall, Toward a theory of international new ventures. Journal of International Business Studies, 1994. 25(1): p. 45-64.

31. Tan, E.N., G. Smith, and M. Saad, Managing the global supply chain: a SME perspective. Production Planning and Control, 2006. 17(3): p. 238-246. 